УДК 657.1

DOI: https://doi.org/10.26642/jen-2019-4(90)-141-147

В.П. Гринь, к.е.н.
Запорізький національний університет

\title{
Сутність та види облікового інформаційного простору
}

Обгрунтовано необхідність проведення наукових досліджень щьодо використання поняття «інформачійного простору в системі бухгалтерському обліку». Виокремлено можливі підходи дослідників до використання поняття «інформаційного простору в бухгалтерському обліку». Проаналізовано підходи дослідників до розуміння сутності облікового інформаційного простору. Обтрунтовано доцільність використання поняття «єдиного інформаційного простору» щодо окремого виду бухгалтерського обліку. Виявлено відсутність єдності в підходах дослідників щзодо розуміння сутності та змістовного наповнення поняття «облікового інформаційного простору». Запропоновано розуміння даного поняття як сукупності різноманітних видів

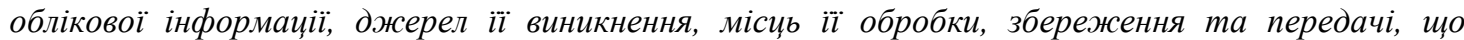
стосується як обліково-інформаційної системи окремої бізнес-одиниці (підприємство, група підприсмств), так $і$ окремих елементів такої системи. Обтрунтовано функиї облікового інформаційного простору.

Ключові слова: інформаційний простір; обліковий інформаційний простір; інформаційні ресурси; облікова інформачія.

Актуальність дослідження та постановка проблеми. В останні роки вітчизняними та зарубіжними вченими в сфері бухгалтерського обліку до складу категорійно-понятійного апарату облікової науки почали вводити нові поняття, які характеризують нові явища або окремі елементи, що виділяються у їх складі. Одним із таких понять є «обліковий інформаційний простір», що характеризує певним чином структуроване та організоване інформаційне середовище для забезпечення конкретних цілей суб'єктів прийняття управлінських рішень. У той же час, незважаючи на достатню поширеність цього поняття в науковій літературі, його зміст розроблений недостатньо, внаслідок чого дана проблематика потребує привернення уваги науковців.

На думку проф. М.І. Сидорової, основною причиною існування такої ситуації є те, що в кінці XX століття напрям досліджень у сфері інформаційних технологій змістився в сторону побудови єдиного інформаційного простору [4, с. 176]. Визначальною передумовою таких змін став швидкий розвиток інформаційних та комунікаційних технологій, тотальна інформатизація та комп'ютеризація діяльності підприємств, вільний і порівняно дешевий доступ до мережі Інтернет, поява і впровадження хмарних технологій, сучасних технологій обробки інформації у віддаленому доступі тощо, що дозволило забезпечити більш швидку обробку облікової інформації, удосконалити засоби і технології ії збереження та покращити інформаційну взаємодію з внутрішніми і зовнішніми користувачами. Наведене вище зумовлює актуальність проведення досліджень, спрямованих на обгрунтування сутності поняття «облікового інформаційного простору» та можливостей і варіантів його застосування в бухгалтерському обліку.

Аналіз останніх наукових досліджень i публікацій. Питанням використання поняття «інформаційного простору в бухгалтерському обліку» присвятили праці В.В. Агафонова, Е.А. Баєва, А.В. Баєв, Н.А. Срмакова, С.П. Першин, Т.В. Посохова, О.В. Рожнова, М.І. Сидорова, Н.Н. Хахонова, Т.Н. Шевченко та ін.

Формулювання цілей статті. Основним завданням статті $є$ аналіз варіантів застосування поняття «інформаційного простору в бухгалтерському обліку» та обгрунтування сутності поняття «облікового інформаційного простору».

Викладення основного матеріалу дослідження. Зазвичай дослідники використовують поняття «інформаційного простору» для означення певної інформаційної області або середовища, яке може використовуватись суб'єктами прийняття управлінських рішень для здійснення впливу на керовану підсистему системи управління підприємством. Як зауважують I.В. Кальніцька та А.М. Данилов [9, с. 42-43], разом 3 даним поняттям для означення подібної інформаційної області також використовують такі поняття, як «інформаційне забезпечення», «обліково-інформаційне забезпечення», «обліково-аналітична система», «обліково-інформаційна система», «обліково-аналітичний механізм», «інформаційне поле». Однак вважаємо не зовсім коректним порівняння і ототожнення між собою наведених вище понять, оскільки вони мають різні сфери застосування і характеризують зовсім різний контекст використання та поширення облікової інформації. Вважаємо, що поняття «інформаційного простору» має чіткі межі та відмінні характеристики від інших подібних понять, що зумовлює актуальність його застосування для розвитку наукових основ бухгалтерського обліку в системі управління. 
На сьогодні серед вчених немає єдності в поглядах стосовно розуміння сутності поняття «облікового інформаційного простору» та причин необхідності його включення до складу системи облікових знань. Це обгрунтовується як відсутністю єдиного розуміння сутності поняття «інформаційний простір» у сфері філософських та інформаційно-комп'ютерних наук, оскільки механізм його формування $є$ достатньо складним процесом з технологічної та методологічної точок зору, так і наявністю різних варіантів використання даної концепції в бухгалтерському обліку, що обгрунтовується існуванням різних варіантів iï впровадження в системі обліку для пояснення раніше невідомих та недосліджених явищ (рис. 1).

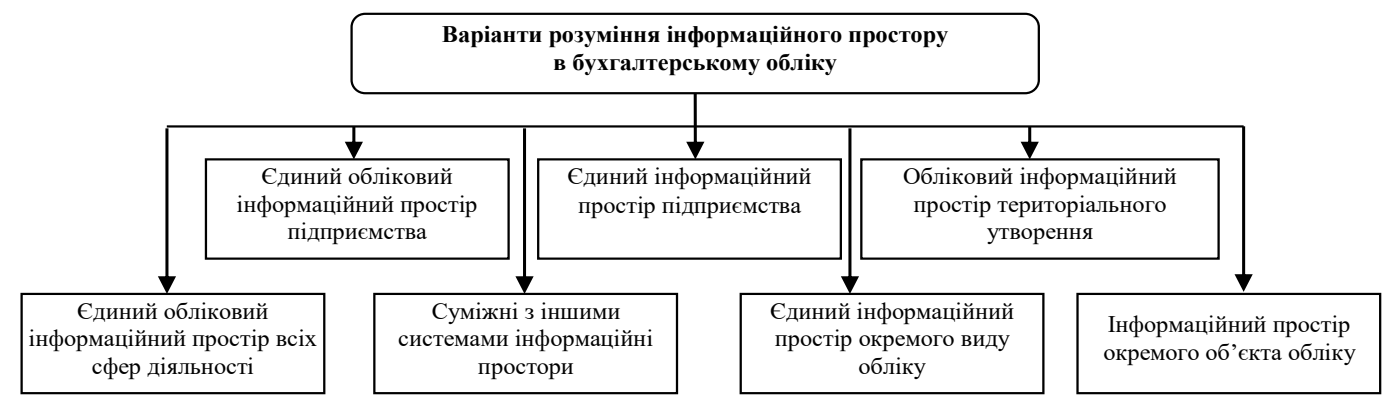

\section{Рис. 1. Можливі підходи дослідників до використання поняття} «інформачійного простору в бухгалтерському обліку»

На сьогодні значна увага питанням побудови єдиного облікового інформаційного простору приділяється у зв'язку 3 бажанням вчених сформувати єдиний інформаційний простір для різних облікових підсистем (фінансового, податкового та управлінського обліку), які функціонують як окремі та незалежні структурні одиниці й забезпечують надання облікової інформації різним групам користувачів. Так М.I. Сидорова [17, с. 20-22] розглядала можливість побудови оптимальної моделі інтеграції різноманітних облікових підсистем в єдиному інформаційному просторі підприємства, зокрема в умовах впровадження МСФЗ, які породжують розширення існуючого інформаційного простору та зумовлюють необхідність посилення існуючих інтеграційних процесів. Такий підхід базується на гіпотезі, що подолання структурного різноманіття облікових підсистем та побудова єдиної інтегрованої системи обліку дозволить зробити обліковий процес більш економічно доцільним та сприятиме підвищенню якості облікової інформації.

Облікова система підприємства завжди була основою для формування інформаційної бази підприємства, тому на сьогодні при формуванні його загального інформаційного простору дослідники наголошують на необхідності інтеграції всіх існуючих облікових систем 3 іншими інформаційними системами в єдину структуру. Так А.М. Кармінський та Б.В. Черніков [10, с. 15-16], Н.Н. Хахонова [22, с. 111] вважають, що типовим прикладом побудови інформаційного простору в межах одного підприємства 3 метою забезпечення проведення аналізу та прийняття управлінських рішень $є$ інтеграція різних видів облікових систем (бухгалтерського, управлінського, стратегічного, виробничого, податкового, виробничо-оперативного тощо) з додаванням до них різних допоміжних інформаційних підсистем (CRM, система електронного документообігу тощо). Застосування такого підходу дозволить зібрати в єдиній структурі всю необхідну інформацію 3 різних джерел та спеціалізованих систем (електронних паперових, комбінованих) для прийняття рішень і до якої можна буде достатньо швидко одержати доступ шляхом встановлення різноманітних видів запитів.

Іншим варіантом використання поняття «інформаційного простору в бухгалтерському обліку»є його формування в рамках певного територіального утворення (країни, економічного територіального об’єднання тощо, на глобальному рівні) 3 метою забезпечення гармонізації облікових практик та полегшення процедур обробки та інтерпретації інформації заінтересованими користувачами. Зокрема, М.А. Гордова [5] наголошує на необхідності формування облікового інформаційного простору в межах територій держав-членів Євразійського економічного союзу, що на іiі думку сприятиме як підвищенню якості облікової інформації, так і зростанню інвестиційної привабливості підприємств, що входять до такого утворення.

В останні роки окремі вчені зазначають про поступове формування глобального облікового інформаційного простору, що стало результатом міжнародної гармонізації облікових систем та поступове приведення їх до певного рівня одноманітності, що є ще одним прикладом виділення інформаційного простору за територіальною ознакою. Так, В.В. Кудряшова, В.В. Марков та О.Б Удачіна зауважують, що в кінці ХХ століття під впливом глобалізації починається створення єдиного світового інформаційного простору, що об'єднує інформаційні системи різних держав через різке зростання ролі інформації [12, с. 87], при цьому автори наголошують, що на сьогодні вже сформувався подібний 
глобальний обліковий інформаційний простір на мікрорівні, що є наслідком процесів глобалізації світової економіки. Однак з таким твердженням авторів досить важко погодитись, оскільки, незважаючи на існуючі тенденції стандартизації та гармонізації національних облікових систем, на сьогодні існують значні відмінності в методології бухгалтерського обліку в різних країнах, що підтверджує відсутність єдиної глобальної моделі обліку та наявність цілої групи конкуруючих парадигм - IAS/IFRS, GAAP US, GAAP UK, стандарти обліку ісламських країн тощо.

Іншою формою інтеграції 3 метою побудови єдиного інформаційного простору підприємства $€$ об'єднання облікових підсистем різних суб'єктів господарювання, що належать до різних видів діяльності. На думку А.В. Бодяко [3, с. 192], І.А. Слободняка та Т.Г. Арбатської [19, с. 44] в межах інформаційного простору мають бути об'єднані підсистеми 3 різних сфер діяльності - облікові підсистеми комерційних організацій, облікові підсистеми установ сектору державного управління та облікові системи в організаціях фінансової сфери. Основною перепоною, яка не дозволяє забезпечити формування такого простору, є відсутність єдиних теоретико-методологічних засад ведення обліку у суб'єктів, що належать до даних сфер.

Ще одним варіантом використання теоретичного концепту інформаційного простору в бухгалтерському обліку $є$ побудова інтегрованого інформаційного простору на основі використання облікового та інших інформаційних просторів (контрольного, аналітичного, податкового тощо). Так С.П. Першин та Т.В. Посохова [13] пропонують формувати єдиний обліковий інформаційний простір на базі єдиної інформаційної облікової системи управління і контролю, В.В. Агафонова [1, с. 151] - єдиний інформаційний простір бухгалтерського обліку, аналізу та аудиту, а Л.В. Титенко - єдиний інформаційний простір обліково-аналітичного забезпечення [20, с. 1408]. М.Ф. Сафонова [16, с. 47] пропонує розробляти єдиний обліково-податковий інформаційний простір 3 метою вирішення проблем облікового забезпечення системи податкового планування, прогнозування i контролю податкових ризиків, зменшення рівня податкових витрат. У цьому разі слід говорити про адаптацію облікової системи підприємства під запити окремої групи користувачів облікової інформації, що в окремих випадках може перешкоджати ефективному виконанню обліковою системою своїх функцій відносно інших видів користувачів.

3 позиції подальшого розвитку облікової науки найбільш важливе значення використання поняття «інформаційного простору» має відносно окремий вид обліку, оскільки дозволяє відмежувати інформаційне середовище, що формується в межах окремого виду обліку від облікової системи підприємства та від загального інформаційного простору підприємства. Одним з перших дослідників, хто розглянув поняття «інформаційного простору» відносно окремого виду обліку, зокрема фінансового обліку, була проф. О.В. Рожнова, якою, виходячи із загального розуміння облікового інформаційного простору, було виокремлено інформаційний простір фінансового обліку [14, с. 21]. Основна мета, яку переслідувала автор при впроваджені даного поняття, полягала в підвищенні рівня інформаційної підтримки користувачів фінансового обліку. Інформаційний простір фінансового обліку може бути представлений двома видами просторів: 1) первісно сформований за результатами функціонування підсистеми фінансового обліку простір; 2) вторинно одержаний простір у результаті сприйняття користувачами інформації з підсистеми фінансового обліку.

Подібно до наведеної вище концепції, розробленої О.В. Рожновою, проф. Н.А. Срмакова [7, с. 21] запропонувала вирізняти інформаційно-економічний простір управлінського обліку, що $€$ одним 3 елементів загального інформаційно-економічного простору підприємства. Під даним поняттям автор розуміє інформаційні ресурси, сформовані із застосуванням теоретико-методологічних і методичних прийомів і засобів управлінського обліку, підтримувані засобами інформаційної інфраструктури, які забезпечують інфокомунікації на рівні суб'єкта господарювання [8, с. 34]. На сьогодні концепція простору управлінського обліку використовується також й іншими дослідниками (Т.Н. Шевченко [23, с. 105], М.І. Сидорова, А.А. Гуляєва [18, с. 50]), а їі впровадження в практичну діяльність підприємств вважається результатом ії інтелектуалізації.

Дослідники, які використовують поняття «просторів фінансового та управлінського обліку», порівнюють їх між собою, відокремлюючи варіанти їх взаємодії, сфери перетину між ними та відмінні особливості, пріоритетність формування i розвитку того або іншого простору для забезпечення зростаючих потреб користувачів облікової інформації. Зокрема, значна кількість дослідників наголошує, що інформаційний простір управлінського обліку може включати значну частину простору фінансового обліку, що залежить на конкретному підприємстві від особливостей впровадженої на ньому системи управління.

Виходячи з існування наведених вище пропозицій щодо виокремлення інформаційних просторів за різними видами обліку, доцільним також $є$ формування облікового інформаційного простору і для інших видів обліку, зокрема, податкового, стратегічного, екологічного, соціального та ін., що дозволить підвищити рівень інформаційної підтримки користувачів, зокрема забезпечити генерування більш 
якісної інформації, що формується в межах відповідних облікових підсистем (податкового, стратегічного, екологічного, соціального обліку тощо) для задоволення їх зростаючих потреб.

Деякі дослідники також наголошують, що можна формувати інформаційний простір для окремого об'єкта обліку. Так Д.М. Трачова розробила концептуальний фреймворк єдиного обліковоінформаційного простору амортизаційної політики [21, с. 362]. Однак такі пропозиції вважаємо не зовсім доцільними, оскільки основною метою формування інформаційного простору є здійснення синтезу інформаційних ресурсів відповідно до потреб користувачів. А оскільки вузькоспеціалізована інформація про окремий об'єкт обліку не надається користувачам окремо, а лише в сукупності з іншою обліковою інформацією, тому побудова окремого інформаційного простору для таких цілей $є$ не зовсім доречною.

Для визначення і обгрунтування сутності поняття «обліковий інформаційний простір» необхідно встановити, що взагалі розуміється під інформаційним простором підприємства, яким чином співвідноситься дане поняття 3 іншими поняттями i категоріями, які використовуються в бухгалтерському обліку для обгрунтування певного інформаційного поля, що формується суб'єктами ведення і організації бухгалтерського обліку та використовується користувачами для прийняття різних видів рішень.

Поняття «інформаційного простору» є достатньо багатогранним, оскільки може стосуватись як певного територіального утворення, економічної системи, галузі, підприємства тощо. Розглядаючи філософські основи даного поняття, слід намагатись їх екстраполювати відносно окремого підприємства, оскільки саме інформаційний простір підприємства напряму стосується системи бухгалтерського обліку, яка $є$ його основним компонентом.

Необхідність формування на підприємстві інформаційного простору є наслідком комп’ютеризації та інформатизації діяльності підприємств, яка поступово призводить до перенасичення інформаційними ресурсами, що зумовлює необхідність використання таких структур їх збереження, обробки та представлення, які б забезпечували максимальну ефективність прийняття управлінських рішень. Саме такою організаційною структурою $\epsilon$ інформаційний простір, який дозоляє забезпечити високоорганізований синтез інформаційних ресурсів і організувати швидкий та релевантний доступ до них. Виходячи з сутності поняття «інформаційного простору», його використання дозволяє визначити структуру та методи формування і представлення інформації на рівні системи управління окремого підприємства та вивчати рівень її впорядкованості, релевантності, інтенсивності формування та передачі.

Серед дослідників, які займаються вивченням сутності інформаційного простору 3 філософської точки зору, немає повної єдності в поглядах стосовно його структурних компонентів, хоча переважно їх позиції є досить схожими. Так В.І. Гриценко, М.І. Вовк, А.Б. Котова до складу інформаційного простору зараховують структуровані інформаційні ресурси, мережеві інформаційні технології та телекомунікаційні елементи [6, с. 14], а М.В. Каткова - інформаційні ресурси, інформаційну інфраструктуру та засоби інформаційної взаємодії [11, с. 25].

Виходячи 3 використання поняття «інформаційного простору на рівні підприємства» під інформаційними ресурсами як елементом інформаційного простору слід розуміти сукупність даних та інформації у вигляді окремих документів, масивів документів, регістрів та звітів в інформаційних системах підприємства. Засоби інформаційної інфраструктури - це сукупність різноманітних інформаційних технологій, які використовуються відповідними суб'єктами для обробки і перетворення інформаційних ресурсів відповідно до потреб користувачів. Засоби інформаційної взаємодії - це сукупність засобів, які забезпечують зворотний зв'язок між суб'єктами обробки і перетворення інформаційних ресурсів та ii користувачами, надаючи доступ і забезпечуючи представлення та трансляцію інформаційних ресурсів у необхідному візуалізованому вигляді.

Побудова інформаційного простору підприємства є складним процесом, що передбачає необхідність інтеграції інформаційних ресурсів, засобів інформаційної інфраструктури та засобів інформаційної взаємодії, різних видів суб'єктів, що використовують наведені вище засоби, та кінцевих користувачів інформації. Основними завданнями, які ставляться при первинній побудові та подальшому розвитку інформаційного простору, є забезпечення швидкості одержання і представлення необхідної інформації користувачам у мінливих економічних умовах. Їх досягнення передбачає здійснення суб'єктами організації інформаційного простору скоординованого комплексу дій, спрямованих на забезпечення ефективної взаємодії його основних елементів, зокрема комунікаційної взаємодії з користувачами інформації.

Базуючись на концепції інформаційного простору, сучасні дослідники в сфері бухгалтерського обліку виокремлюють поняття «облікового інформаційного простору» або його окремих видів (інформаційний простір управлінського або фінансового обліку), що наведені в таблиці 1. 
Підходи дослідників до розуміння сутності облікового інформаційного простору

\begin{tabular}{|c|c|}
\hline Автор & Визначення облікового інформачійного простору або його видів \\
\hline $\begin{array}{l}\text { В.В. Агафонова } \\
\quad[1, \text { с. } 151]\end{array}$ & $\begin{array}{l}\text { Інформаційний простір обліку аналізу і аудиту - це інформація, яка } \\
\text { використовується в сфері виробничо-господарської діяльності, i система } \\
\text { відносин, пов'язаних } 3 \text { формуванням, передачею та сприйняттям необхідних } \\
\text { даних і знань }\end{array}$ \\
\hline $\begin{array}{l}\text { Є.А. Баєва, } \\
\text { А.В. Баєв } \\
{[2, \text { с. } 16]}\end{array}$ & $\begin{array}{l}\text { Облікове інформаційне поле (простір) є одним із сегментів інформаційного поля, } \\
\text { що генерує бухгалтерську інформацію }\end{array}$ \\
\hline М.А. Гордова [5] & $\begin{array}{l}\text { Сдиний обліковий простір - це впорядкована відповідно до визначених } \\
\text { принципів сукупність облікової інформації, призначеної для прийняття рішень } \\
\text { стейкхолдерами в умовах ризику і невизначеності }\end{array}$ \\
\hline $\begin{array}{l}\text { Н.А. Срмакова } \\
\qquad[8, \text { с. } 34]\end{array}$ & $\begin{array}{l}\text { Обліковий інформаційний простір - це сукупність інформаційних ресурсів у } \\
\text { вигляді бухгалтерської інформації (фінансової та управлінської), яка все більше } \\
\text { розширює межі своєї присутності, вступаючи у взаємодію } 3 \text { іншими } \\
\text { компонентами інформаційного простору }\end{array}$ \\
\hline $\begin{array}{l}\text { С.П. Першин, } \\
\text { Т.В. Посохова } \\
\quad[13]\end{array}$ & $\begin{array}{l}\text { Сдиний обліковий простір - це деяке інформаційне облікове середовище } \\
\text { узагальнення та обміну обліковими відомостями, що функціонує за } \\
\text { встановленими правилами і нормами згідно } 3 \text { компетенцією їі учасників і } \\
\text { користувачів обліковими відомостями. }\end{array}$ \\
\hline \multirow[t]{2}{*}{$\begin{array}{l}\text { О.В. Рожнова } \\
{[14, \text { c. } 21,37]}\end{array}$} & $\begin{array}{l}\text { Інформаційний простір фінансового обліку - це інформація, що генерується в } \\
\text { сфері фінансового обліку, і система інформаційних відносин } 3 \text { приводу ії } \\
\text { формування, передачі та сприйняття }\end{array}$ \\
\hline & $\begin{array}{l}\text { Обліковий інформаційний простір - це цілісне утворення інформаційних } \\
\text { ресурсів, що репрезентують множину об'єктів }\end{array}$ \\
\hline $\begin{array}{l}\text { I.I. Сардачук } \\
{[15, \text { c. } 512]}\end{array}$ & $\begin{array}{l}\text { Суб’єкти господарювання, що надають інформацію про свою діяльність та ії } \\
\text { результати, формують певний масив облікового інформаційного простору }\end{array}$ \\
\hline $\begin{array}{l}\text { Л.В. Титенко } \\
{[20, \text { с. } 1409]}\end{array}$ & $\begin{array}{l}\text { Інформаційний простір підприємства, більша частина якого формується } \\
\text { системою бухгалтерського обліку, є сукупністю різнорідних зовнішніх і } \\
\text { внутрішніх інформаційних потоків }\end{array}$ \\
\hline $\begin{array}{l}\text { Т.Н. Шевченко } \\
\text { [23, с. 107] }\end{array}$ & $\begin{array}{l}\text { Інформаційний простір управлінського обліку - це інформаційні ресурси, } \\
\text { утворені за допомогою застосування управлінського обліку }\end{array}$ \\
\hline
\end{tabular}

Виходячи з наведених вище визначень облікового інформаційного простору та його видів (табл. 1) можна констатувати, що дані поняття однозначно не визначені термінологічно, і серед авторів не існує спільної думки щодо їх сутності. Поняття «обліковий інформаційний простір» розглядається дослідниками як синонім таких понять, як інформаційне поле, область, сфера або середовище, що також свідчить про відсутність єдиного розуміння щодо його структурних елементів. Спільним у більшості поглядів вчених стосовно цього поняття $є$ його розуміння як складової загального інформаційного простору підприємства та включення до складу його елементів різних варіантів групування інформації (дані, знання, інформаційні ресурси, інформаційні потоки). Існування відмінностей в підходах дослідників пояснюється тим, що обліковий інформаційний простір не є гетерогенним, до складу якого входять підпростори (управлінського обліку, фінансового обліку тощо), в яких об'єкти, методи і процеси обробки та форми представлення інформації різняться. Тому дане поняття і його зміст потребують уточнення з врахуванням особливостей функціонування облікової інформаційної технології та потреб і вимог користувачів облікової інформації в умовах сьогодення.

Висновки та перспективи подальших досліджень. Проведений аналіз розуміння сутності поняття «інформаційний простір» в філософській літературі дозволив встановити, що обліковий інформаційний простір - це сукупність різноманітних видів облікової інформації, джерел іiі виникнення, місць іiі обробки, збереження та передачі, що стосується як обліково-інформаційної системи окремої бізнесодиниці (підприємство, група підприємств), так і окремих елементів такої системи. До складу облікового інформаційного простору входять облікові інформаційні ресурси, тобто облікова інформація різних видів, обліково-інформаційна інфраструктура та засоби забезпечення обліково-інформаційної взаємодії між суб'єктами ії створення, перетворення, представлення та трансляції користувачам.

Обліковий інформаційний простір підприємства виконує такі функції:

- $\quad$ організація, інтеграція, структуризація та змістовне агрегування всіх облікових інформаційних ресурсів підприємства; 
- $\quad$ інтенсифікація використання облікових інформаційних ресурсів у процесі прийняття рішень внутрішніми і зовнішніми користувачами; асиметрії.

забезпечення ефективності функціонування ринків капіталу шляхом зменшення інформаційної

\section{Список використаної літератури:}

1. Агафонова B.B. Единое информационное пространство бухгалтерского учета, анализа и аудита / B.В. Агафонова // Вестник Самарского государственного аэрокосмического университета. - 2002. - № 1. C. 151-158.

2. Баева E.A. Компоненты учетно-информационного пространства организации / Е.А. Баева, А.В. Баев // Социально-экономические явления и процессы. - 2012. - № 10 (44). - С. 16-20.

3. Бодяко A.B. Проблемы развития методологии учета и контроля в условиях институциональной экономики инновационного типа. Т. 2. Современные тенденции институционализации экономики и учетного пространства / А.В. Бодяко. - М. : Русайнс, 2017. - 248 с.

4. Бухгалтерский учет в современных бизнес-структурах : монография / под ред. М.А. Вахрушиной. - М. : Финансовый университет, 2017. - 235 с.

5. Гордова М.A. Методика гармонизации бухгалтерского учета государств-членов Евразийского экономического союза в условиях цифровой экономики / М.А. Гордова // Науковедение : интернет-журнал. - 2017. - Т. 9, № 5 [Электронный ресурс]. - Режим доступа : https://naukovedenie.ru/PDF/83EVN517.pdf.

6. Гриценко B.I. Введення в архітектоніку інформаційного простору. Моделі. Проблеми розвитку / B.I. Гриценко, М.I. Вовк, А.Б. Котова. - К. : Наукова думка, 2003. - 168 с.

7. Ермакова Н.А. Контрольно-информационные системы в экономическом пространстве управленческого учета : дис. ... доктора экон. наук : 08.00.12 / Н.А. Ермакова. - Казань, 2005. - 416 с.

8. Ермакова Н.A. Не хлебом единым: управленческий учет - составная часть информационной обеспеченности предприятия / Н.А. Ермакова // Российское предпринимательство. - 2006. - № 12. - С. 32-35.

9. Кальницкая И.В. Учетно-аналитические системы организации : монография / И.В. Кальницкая, А.Н. Данилов. Scientific magazine «Kontsep», 2014. - 136 c.

10. Карминский А.М. Информационные системы в экономике : в 2-х ч. Ч. 1. Методология создания : учеб. пособие / А.М. Карминский, Б.В. Черников. - М. : Финансы и статистика, 2006. -336 с.

11. Каткова М.B. Понятие «информационное пространство» в современной социальной философии / М.В. Каткова // Известия Саратовского университета. Серия : Философия. Психология. Педагогика. - 2008. T. 8, Вып. 2. - С. 23-26.

12. Кудряшова B.B. Глобализация: понятие и роль в формировании единого учетного информационного пространства / В.В. Кудряшова, В.В. Марков, Е.Б. Удачина // Известия МГТУ «МАМИ». - 2013. - № 4 (18), T. 1. - C. $82-90$.

13. Першин С.П. Единое учетное пространство и учетные агенты как приемы развития бухгалтерского учета / С.П. Першин, Т.В. Посохова // Научный журнал КубГАУ. - 2016. - № 118 (04) [Электронный ресурс]. - Режим доступа : http://ej.kubagro.ru/2016/04/pdf/34.pdf.

14. Рожнова О.В. Финансовый учет. Теоретические основы, методологический аппарат / О.В. Рожнова. - 2-е изд., перераб. и доп. - М. : Экзамен, 2003. - 192 с.

15. Сардачук I.I. Обліково-інформаційне забезпечення внутрішньогосподарського контролю / I.I. Сардачук // Вісник національного університету «Львівська політехніка». - 2009. - № 647. - С. 509-514.

16. Сафонова М.Ф. Налоговые затраты и контроль за их состоянием в системе учетно-налогового информационного пространства / М.Ф. Сафонова // Учет. Анализ. Аудит. - 2015. - № 6. - С. $45-57$.

17. Сидорова М.И. Модели интеграции различных учетных подсистем в единое информационное пространство / М.И. Сидорова // Международный бухгалтерский учет. - 2013. - № 30 (276). - С. 20-27.

18. Сидорова М.И. Управленческий учет как элемент единого информационного пространства организации / М.И. Сидорова, А.А. Гуляева // Учет. Анализ. Аудит. - 2016. - № 5. - С. 50-65.

19. Слободняк И.А. Единая теория бухгалтерского учета как необходимое и достаточное условие формирования единого учетного пространства / И.А. Слободняк, Т.Г. Арбатская // Учет, анализ, аудит. - 2015. - № 3. - С. 44-50.

20. Титенко Л.В. Логістичні принципи формування обліково-аналітичного забезпечення стратегічного управління підприємством / Л.В. Титенко // Економіка і суспільство. - 2017. - Вип. 13. - С. 1408-1418.

21. Трачова Д.М. Обліково-інформаційне забезпечення формування амортизаційної політики : теорія, методологія, організація : дис. ... доктора екон. наук : спец. 08.00.09 - бухгалтерський облік, аналіз та аудит (за видами економічної діяльності) / Д.М. Трачова. - К. : ННЦ «ІАЕ» НААНУ, 2018. - 555 с.

22. Хахонова Н.Н. Место учета в системе единого информационного пространства организации / Н.Н. Хахонова // Государственное и муниципальное управление. Ученые записки СКАГС. - 2015. - № 4. - С. 108-112.

23. Шевченко T.H. Концептуальные основы формирования информационно-экономического пространства управленческого учета / T.Н. Шевченко // Известия Иссык-Кульского форума бухгалтеров и аудиторов стран Центральной Азии. - 2014. - № 3 (6). - С. 104-112.

\section{References:}

1. Agafonova, V.V. (2002), «Edinoe informacionnoe prostranstvo buhgalterskogo ucheta, analiza i audita», Vestnik Samarskogo gosudarstvennogo ajerokosmicheskogo universiteta, No. 1, pp. 151-158. 
2. Baeva, E.A. and Baev, A.V. (2012), «Komponenty uchetno-informacionnogo prostranstva organizacii», Social'nojekonomicheskie javlenija i processy, No. 10 (44), pp. 16-20.

3. Bodjako, A.V. (2017), Problemy razvitija metodologii ucheta i kontrolja v uslovijah institucional'noj jekonomiki innovacionnogo tipa, Vol. 2 «Sovremennye tendencii institucionalizacii jekonomiki i uchetnogo prostranstva», Rusajns, Moskva, $248 \mathrm{p}$.

4. Vahrushina, M.A. (ed.) (2017), Buhgalterskij uchet $v$ sovremennyh biznes-strukturah, monografija, Finansovyj universitet, Moskva, $235 \mathrm{p}$.

5. Gordova, M.A. (2017), «Metodika garmonizacii buhgalterskogo ucheta gosudarstv-chlenov Evrazijskogo jekonomicheskogo sojuza v uslovijah cifrovoj jekonomiki», Naukovedenie, Vol. 9, No. 5, [Online], available at: https://naukovedenie.ru/PDF/83EVN517.pdf

6. Grycenko, V.I., Vovk, M.I. and Kotova, A.B. (2003), Vvedennja v arhitektoniku informacijnogo prostoru. Modeli. Problemy rozvytku, Naukova dumka, Kyi'v, 168 p.

7. Ermakova, N.A. (2005), Kontrol'no-informacionnye sistemy v jekonomicheskom prostranstve upravlencheskogo ucheta, D. Sc. Thesis, 08.00.12, Kazan', 416 p.

8. Ermakova, N.A. (2006), «Ne hlebom edinym: upravlencheskij uchet - sostavnaja chast' informacionnoj obespechennosti predprijatija», Rossijskoe predprinimatel'stvo, No. 12, pp. 32-35.

9. Kal'nickaja, I.V. and Danilov, A.N. (2014), Uchetno-analiticheskie sistemy organizacii afija, monografija, Scientific magazine «Kontsep», $136 \mathrm{p}$.

10. Karminskij, A.M. and Chernikov, B.V. (2006), Informacionnye sistemy v jekonomike, Part 1 «Metodologija sozdanija», Finansy i statistika, Moskva, $336 \mathrm{p}$.

11. Katkova, M.V. (2008), «Ponjatie «informacionnoe prostranstvo» v sovremennoj social'noj filosofii», Izvestija Saratovskogo universiteta, Serija Filosofija. Psihologija. Pedagogika, Vol. 8, Issue 2, pp. 23-26.

12. Kudrjashova, V.V., Markov, V.V. and Udachina, E.B. (2013), «Globalizacija: ponjatie i rol' v formirovanii edinogo uchetnogo informacionnogo prostranstva», Izvestija MGTU «MAMI», No. 4 (18), Vol. 1, pp. 82-90.

13. Pershin, S.P. and Posohova, T.V. (2016), «Edinoe uchetnoe prostranstvo i uchetnye agenty kak priemy razvitija buhgalterskogo ucheta», Nauchnyj zhurnal KubGAU, No. 118 (04), [Online], available at: https: http://ej.kubagro.ru/2016/04/pdf/34.pdf

14. Rozhnova, O.V. (2003), Finansovyj uchet. Teoreticheskie osnovy, metodologicheskij apparat, 2nd ed., Izdatel'stvo «Jekzamen», Moskva, $192 \mathrm{p}$.

15. Sardachuk, I.I. (2009), «Oblikovo-informacijne zabezpechennja vnutrishn'ogospodars'kogo kontrolju», Visnyk nacional'nogo universytetu «L'vivs'ka politehnika», No. 647, pp. 509-514.

16. Safonova, M.F. (2015), «Nalogovye zatraty i kontrol' za ih sostojaniem v sisteme uchetno-nalogovogo informacionnogo prostranstva», Uchet. Analiz. Audit, No. 6, pp. 45-57.

17. Sidorova, M.I. (2013), «Modeli integracii razlichnyh uchetnyh podsistem v edinoe informacionnoe prostranstvo», Mezhdunarodnyj buhgalterskij uchet, No. 30 (276), pp. 20-27.

18. Sidorova, M.I. and Guljaeva, A.A. (2016), «Upravlencheskij uchet kak jelement edinogo informacionnogo prostranstva organizacii », Uchet. Analiz. Audit, No. 5, pp. 50-65.

19. Slobodnjak, I.A. and Arbatskaja, T.G. (2015), «Edinaja teorija buhgalterskogo ucheta kak neobhodimoe i dostatochnoe uslovie formirovanija edinogo uchetnogo prostranstva», Uchet, analiz, audit, No. 3, pp. 44-50.

20. Tytenko, L.V. (2017), «Logistychni pryncypy formuvannja oblikovo-analitychnogo zabezpechennja strategichnogo upravlinnja pidpryjemstvom», Ekonomika i suspil'stvo, Vol. 13, pp. 1408-1418.

21. Trachova, D.M. (2018), Oblikovo-informacijne zabezpechennja formuvannja amortyzacijnoi' polityky: teorija, metodologija, organizacija, D. Sc. Thesis,, spec. 08.00.09 - buhgalters'kyj oblik, analiz ta audyt (za vydamy ekonomichnoi' dijal'nosti), NNC «IAE» NAANU, Kyi'v, 555 p.

22. Hahonova, N.N. (2015), «Mesto ucheta v sisteme edinogo informacionnogo prostranstva organizacii», Gosudarstvennoe i municipal'noe upravlenie. Uchenye zapiski SKAGS, No. 4, pp. 108-112.

23. Shevchenko, T.N. (2014), «Konceptual'nye osnovy formirovanija informacionno-jekonomicheskogo prostranstva upravlencheskogo ucheta», Izvestija Issyk-Kul'skogo foruma buhgalterov i auditorov stran Central'noj Azii, No. 3 (6), pp. 104-112.

Вікторія Петрівна Гринь - кандидат економічних наук, доцент кафедри обліку та оподаткування Запорізького національного університету.

Наукові інтереси:

- теорія стратегічного управління;

- стратегічний облік;

- облікове забезпечення стратегічного управління.

E-mail: viktoriya_grin@ukr.net.

Стаття надійшла до редакції 03.10.2019. 